\title{
A Comparative Analysis of the Use of Expressions of Gratitude between Seniors and Juniors among College Students in Korea and Japan
}

\author{
Yongil Park \\ College of Liberal Arts, Catholic University of Pusan,57 Oryundero, Gumjung-gu, \\ Pusan 46252, Korea \\ ugclub@naver.com
}

\begin{abstract}
The aim of this study is to conduct a comparative analysis on the daily use of expressions of gratitude among college students in Korea and Japan and identify their differences or distinctive features in an effort to examine them from a psychological perspective. More specifically, this study focuses on the students with a senior-junior relationship, their interaction involving the expressions of gratitude, and what it reveals about their psychological state. For the purpose of obtaining data, two groups of 14 college students, in Korea and Japan respectively, were provided with a scenario where a junior student received assistance from a senior. The subjects were then surveyed using the Psychological Test and Discourse Completion Test. The findings of the survey are summarized as follows: First, a significantly higher percentage of Korean students (77.3\%) answered they "felt grateful toward their seniors" than their Japanese counterparts, and the most commonly used expression in Korean was 'Thank you'. About 51.9\% of Japanese students said they felt grateful, and 29.5\% of them answered they felt sorry. With regard to the expressions, two of the most frequently used were 'Thank you' and 'I am sorry', respectively. Secondly, it turned out that the Korean students were using expressions of 'offering' something, such as meal or coffee, on a daily basis as a token of appreciation in the form of 'To buy (a meal or tea)'. On the contrary, none of the Japanese students said they were using 'To buy (a meal or tea)' or its equivalent to express their gratitude. Thirdly, only $1.7 \%$ of the Korean students agreed to the statement "I think I caused a trouble to my senior", whereas the number skyrocketed to 14\% among the Japanese participants.
\end{abstract}

Keywords: Gratitude Expressions, Korean University Students, Japanese Students, Seniors and Juniors, Comparative Analysis

\section{Introduction}

The current study seeks to understand the difference between Korean and Japanese by analyzing expressions used in the real-world discourse of Korean and Japanese college students. Gratitude expressions were selected for consideration in the current study because they can emerge in different forms when used in the real world. For example, a typical gratitude expression in Japanese is "arigatou (Thank you)," but in certain situations "sumimasen (I'm

Article history:

Received (January 13, 2019), Review Result (April 2, 2019), Accepted (May 27, 2019) 
sorry)," which is an apology expression, may be used to display the feeling of gratitude.[1] Such Japanese gratitude expressions, analyzed in conjunction with discourse in the same situations that involve Korean gratitude expressions, clearly demonstrate the difference between the two languages.

A: Landlady B: Renter (college student)

(Situation: Phone conversation)

A: ... Please take care of the contract document that we just discussed.

B: ... Okay, noted.

(Situation: At the landlady's home)

B: ... I brought the document here.

A: ... Oh, really?! You came all the way here to bring it. Thank you.

What can be understood in the above Korean and Japanese discourses is that although "sumimasen (I'm sorry)" in Japanese is generally used as a typical apology expression, it can also be used as a gratitude expression depending on the situation. Korean speakers use the typical gratitude expression ("gomaweyo (Thank you)").

\section{Precedent Research}

There has been extensive research on expressions of gratitude in Japanese.[2][3] For example, studies on gratitude expressions such as Kumatoriya (1988), Kumatoriya (1994), and Miyake (1994) focus on situations in which Japanese apology expressions can be used to display gratitude. Using Brown and Levinson (1987)'s speech act theory, Kumatoriya (1994) explained that "sumimasen (I'm sorry)," a typical Japanese apology expression, can be used as a gratitude expression.[4] Miyake (1994) pointed out that Japanese people often use apology expressions even in situations that do not warrant an apology. Ogosi (1994) pointed to the differences among gratitude expressions within Japanese and Korean, as well as the differences between Japanese gratitude expressions and Korean gratitude expressions. For example, the study noted that in Japanese, gratitude expressions and apology expressions form an internalexternal relationship, but no such relationship exists in Korean.[5]

\section{Research Method}

Fourteen college students, each from either Japan or Korea, were recruited for the survey used in the current study. The two groups comprised seven men and seven women each, and the survey was conducted between March 2014 and June 2015. The average age of the Japanese college students was 20.2 years, and that of their Korean counterparts was 21.3 years. One of the focus areas of the analysis in the current study was the psychological factors at play when survey respondents used gratitude expressions. For this reason, the survey used in the current study utilized the Psychological Test (PT)[6][7] and Discourse Completion Test (DCT)[8]. The following sections will describe PT and DCT used in the study to extract data.

\subsection{PT (Psychological Test)}

This survey was developed by referencing Gu and Yeo (2012) to establish the following four questions regarding the psychological state of the speaker:

(1) Do you feel gratitude toward the other person?

(2) Do you feel a sense of apology toward the other person?

(3) Do you feel that you have inconvenienced the other person? 
(4) Do you feel indebted to the other person?

\subsection{DCT (Discourse Completion Test)}

In the current study, the relationship between the subjects and the other person to whom the feeling of gratitude is expressed was categorized into that of "inside" and "outside." "Inside" referred to relationships within the same academic department or extracurricular club, while "outside" signified relationships with people in different academic departments or different extracurricular club. These relationships were in turn divided into those of more senior and more junior students, and further into the gender of the speaker and the listener. The following excerpts are from the DCT and PT surveys:

- DCT Survey

Let's assume that you are in the following discourse situation.

What would you say to the other person?

Please answer with the expressions that you would most naturally use if it were an actual situation. If you would not say anything in that situation.

Situation: You could not make it to an important class. Later, you visited a more senior college student to whom you are close, to ask about what was discussed during the class.

<Discourse>

You: you were at the 00 class yesterday, right?

Senior College Student: Yes, I was.

You: Please tell me what was said in the 00 class from yesterday.

Senior College Student: Okay. Here. These are my notes from the class.

You: < $>$

$<$ If you would not say anything, describe your gestures or facial expressions. $>$

- PT Survey

Do you feel gratitude toward the other person?

Very much so $5-4-3-2-1$ Not at all

Do you feel a sense of apology toward the other person?

Very much so $5-4-3-2-1$ Not at all

Do you feel that you have inconvenienced the other person?

Very much so $5-4-3-2-1$ Not at all

Do you feel indebted to the other person?

Very much so $5-4-3-2-1$ Not at all

\section{Results}

Table 1 and 2 display the types of gratitude expressions used by the Japanese and Korean college students, as well as the way in which these gratitude expressions appeared, organized by the four PT cases mentioned in Section 3.

Table1. Types and Aspects of Appearance of Gratitude Expressions (J)

\begin{tabular}{|c||c|c|c|}
\hline & Types of Gratitude Expression & Frequency & $\begin{array}{c}\text { Rate of } \\
\text { Appearance }\end{array}$ \\
\hline \hline $\begin{array}{c}\text { When Feeling } \\
\text { Gratitude }\end{array}$ & $\begin{array}{c}\text { "Thank you (gratitude)," "Really?!," "Is } \\
\text { that okay?!," "I'm happy", exclamation } \\
\text { ("Yes!"), Seriously?!, "Of course" or } \\
\text { "Indeed," "Great" }\end{array}$ & 148 times & $51.9 \%$ \\
\hline
\end{tabular}




\begin{tabular}{|c||c|c|c|}
\hline $\begin{array}{c}\text { When Feeling a } \\
\text { Sense of } \\
\text { Apology }\end{array}$ & $\begin{array}{c}\text { "Thank you (gratitude)," "Great," "I'm } \\
\text { sorry," answering words ("Yes"), "Is that } \\
\text { okay?!" }\end{array}$ & 84 times & $29.5 \%$ \\
\hline $\begin{array}{c}\text { When Feeling } \\
\text { that the Other } \\
\begin{array}{c}\text { Person Has } \\
\text { Been } \\
\text { Inconvenienced }\end{array}\end{array}$ & $\begin{array}{c}\text { "Thank you (gratitude)," "Great," "Is that } \\
\text { okay?!," "I'm sorry" }\end{array}$ & 40 times & $14.0 \%$ \\
\hline $\begin{array}{c}\text { When Feeling } \\
\text { Indebted to the } \\
\text { Other Person }\end{array}$ & $\begin{array}{c}\text { "Thank you (gratitude)," "I'm in your debt," } \\
\text { "I look forward to seeing you next time" }\end{array}$ & 13 times & $4.6 \%$ \\
\hline \hline Total & & 285 times & $100 \%$ \\
\hline \hline
\end{tabular}

As shown in Table 1,51.9\% of the Japanese college students used gratitude expressions in the four PT cases presented in the survey. More specifically, there were eight types of expressions, which were: "Thank you" (128 times), "Really?!" (9 times), "Is that okay?" (2 times), "I’m happy" (5 times), exclamation "Yes!" (1 time), "Seriously?!" (1 time), "Of course" (1 time), and "Great" (1 time). Among these types, "Thank you" was used 157 times, which was significantly more frequent than other gratitude expression types. Also, "I'm happy," which displays joy, was used five times by the Japanese college students to express gratitude to the more senior college student with whom they are close. Of note is that this type of expression was used only by female subjects, indicating that women substitute their gratitude expressions by expressing their happiness to the listener. In $29.5 \%$ of PT cases, a gratitude expression was used when the speaker was feeling a sense of apology, indicating that the subjects felt both gratitude and a significant sense of apology when they were helped by the more senior college student. In such cases, five types of gratitude expressions were used: "Thank you" (23 times), "Great" (1 time), "I'm sorry" (8 times), answering word ("yes") (49 times) and "Is that okay?!" (3 times). Here, the "Thank you" type expression appeared 23 times, in addition to the "answering words ("yes")" type (49 times), suggesting that a sense of apology is also displayed through substituted expressions such as "thank you." Gratitude expressions were used in $14 \%$ of the PT cases in which the subjects felt that they had inconvenienced the other person. Here, four types of gratitude expressions were used: "Thank you" (36 times), "Great" (1 time), "Is that okay?!" (2 times), and "I'm sorry" (1 time). These results show that the "Thank you" type of expression was mainly used when the speaker felt that the other person was inconvenienced. The aspect of appearance of gratitude expressions significantly decreased when the speaker felt indebted to the other person; three types of gratitude expressions, "Thank you" (9 times), "I'm in your debt" ( 2 times), and "I look forward to seeing you next time" (2 times), were used.

Table 2 Types and Aspects of Appearance of Gratitude Expressions (K)

\begin{tabular}{|c||c|c|c|}
\hline & Types of Gratitude Expression & Frequency & $\begin{array}{c}\text { Rate of } \\
\text { Appearance }\end{array}$ \\
\hline \hline $\begin{array}{c}\text { When Feeling } \\
\text { Gratitude }\end{array}$ & $\begin{array}{c}\text { "Thank you (gratitude)," "Really?!," "Is } \\
\text { that okay?!," exclamation ("Yes!"), } \\
\text { onomatopoetic or mimetic words, "Of } \\
\text { course" or "Indeed," "To buy" (a meal or } \\
\text { tea) }\end{array}$ & 177 times & $77.3 \%$ \\
\hline
\end{tabular}




\begin{tabular}{|c||c|c|c|}
\hline $\begin{array}{c}\text { When Feeling a } \\
\text { Sense of } \\
\text { Apology }\end{array}$ & $\begin{array}{c}\text { "Thank you (gratitude)," "Really?!," "I'm } \\
\text { sorry," answering words ("Yes"), "To buy" } \\
\text { (a meal or tea) }\end{array}$ & 35 times & $15.3 \%$ \\
\hline $\begin{array}{c}\text { When Feeling } \\
\text { that the Other } \\
\text { Person Has } \\
\text { Been } \\
\text { Inconvenienced }\end{array}$ & $\begin{array}{c}\text { "Thank you (gratitude)," "I'm sorry," "To } \\
\text { buy" (a meal or tea) }\end{array}$ & 4 times & $1.7 \%$ \\
\hline $\begin{array}{c}\text { When Feeling } \\
\text { Indebted to the } \\
\text { Other Person }\end{array}$ & $\begin{array}{c}\text { "Thank you (gratitude)," "I'm in your debt," } \\
\text { "To buy" (a meal or tea) }\end{array}$ & 13 times & $5.7 \%$ \\
\hline \hline \multicolumn{2}{|c|}{} & 229 times & $100 \%$ \\
\hline \hline
\end{tabular}

As Table 2 shows, there were seven types of expression used by the Korean college students when they felt gratitude: "Thank you" (125 times), "Really?" (23 times), "Is that okay?" (2 times), an exclamation ("Yes!") (2 times), onomatopoetic and mimetic words (2 times), and "To buy" (a meal or tea) (23 times). Also, in 77.3\% of the four PT cases mentioned in Section 3 , gratitude expressions were used when the speaker felt gratitude. This indicates that the Korean college students directly say "Thank you" when helped by other people. More specifically, the most frequently used gratitude expression in such a situation was the "Thank you" type (125 times, 77.3\%), which constituted an overwhelmingly large proportion of the total. In $15.3 \%$ of all PT cases, the speakers used gratitude expressions when they felt a sense of apology. In such cases, there were five types of gratitude expressions: "Thank you" (13 times), "Really?" (1 time), "I'm sorry" (3 times), response ("Yes") (1 time), and "To buy" (a meal or tea) (17 times). Of note is the fact that the "To buy" (a meal or tea) type expression was used more frequently than the "Thank you" type of expression. While the "To buy" (a meal or tea) type was used in other PT cases as well, it was more frequently used than the "Thank you" type of expression when the speaker felt indebted or felt a sense of apology toward the other person. In $1.7 \%$ of all PT cases, gratitude expressions were used when the speaker felt that the other person had been inconvenienced. This indicates that when the Korean college students were helped by a more senior college student to whom they were close, they rarely felt that they were inconveniencing the other person. In such cases, three types of gratitude expressions were used: "Thank you" (2 times), "I'm sorry" (1 time), and "To buy" (a meal or tea) (1 time). Gratitude expressions were used when the speaker felt indebted to the other person in 5.7\% of all PT cases. This finding also suggests that the Korean college students did not feel very indebted when they were helped by a more senior college student to whom they were close. In such cases, three types of gratitude expressions were used: "Thank you," "I'm in your debt," "To buy" (a meal or tea).

\section{Conclusion}

Based on the survey results, the Korean and Japanese college students exhibited the following differences in terms of the gratitude expressions. First, the Japanese and Korean college students used different types of gratitude expressions in the PT cases. That is, in $81.4 \%$ of all cases the Japanese college students used gratitude expressions when they felt gratitude (51.9\%) and a sense of apology (29.5\%), but Korean college students used gratitude expressions in $77.3 \%$ of all cases when feeling gratitude. Second, the Korean college students used the "To buy" type of expression indicating their intention to buy a meal, tea, or coffee in 
return, to display their feeling of gratitude. Meanwhile, the Japanese college students used gratitude expressions indicating that they will buy the other person something in return. Third, when they were helped by a more senior college student to whom they are close, the Japanese college students felt they had inconvenienced the other person in $14 \%$ of the cases, but the Korean students rarely felt the same under that situation.

\section{References}

[1] K. Miyake, Kansynotaisyoukenkyuu: Nichieitaisyoukenkyuu, Nihongogaku, Meijisyouin, Tokyo (1994), Vol. 13, pp.10-18.

[2] T. Kumatoriya, Hatuwakouirironto Danwakoudoukaramita Nihongono"wabi”to"kansya." Hirosima daigaku Kyouikugakubukiyou, (1988), Vol.37, pp.223-234.

[3] T. Kumatoriya, Hatuwakouitositenokansya: Tekisetuseizyouken, Hyougennstorage, Danwakinou, Nihongogaku, (1994), Vol.3, pp.63-72.

[4] P. Brown, and P. Levinson, Politeness Some Universals in Language Usage, Cambridge University Press, London (1987).

[5] M. Ogosi, Kansyanotaisyoukenkyuu: Nittyoutaisyoukenkyuu, Nihongogaku (1994), Vol.3, pp.19-27.

[6] M. Yoon, H. Seo, G. Kim, G. Gu, Simrigeomsa:Gebalbuteo Whalyongggaji, Hakgisa, Seoul (2019).

[7] Y. Ku and T. Yeo, Chodeunghkgyou Gyosaui Simrigeomsa Ihedowa Whalyongdo Chodeungsangdamyonggu, (2012), Vol. 11, pp.51-69.

[8] H. Jee, Interview Sihweom Damhwabunseokeul Tonghan Hangukeo Gueoneugryokpyeonggaui Guinyeongu, Gukeo Gyoyukyeongu, (2005), Vol.16, pp.79-104.

\section{Authors}

\section{Yongil Park, Ph.D.}

Assistant Professor, College of Liberal Arts, Catholic University of Pusan, 57 Oryundero, Gumjung-gu, Pusan 46252, Korea 